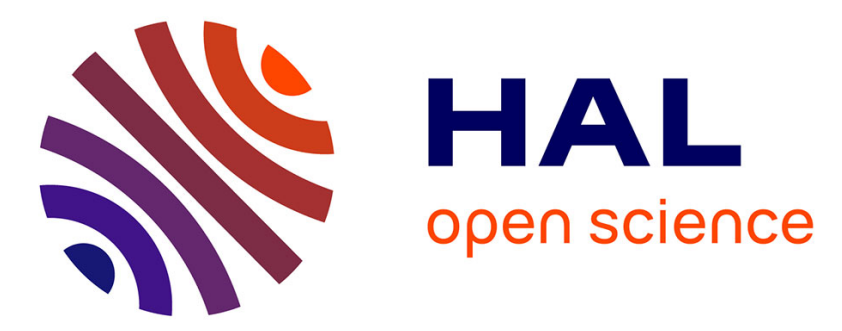

\title{
Digital Safety and Responsible Use Within a Primary School Ecosystems Community in Aotearoa/New Zealand
}

Nicki Dabner

\section{- To cite this version:}

Nicki Dabner. Digital Safety and Responsible Use Within a Primary School Ecosystems Community in Aotearoa/New Zealand. 11th IFIP World Conference on Computers in Education (WCCE), Jul 2017, Dublin, Ireland. pp.19-23, 10.1007/978-3-319-74310-3_3 . hal-01762872

HAL Id: hal-01762872

https://hal.inria.fr/hal-01762872

Submitted on 10 Apr 2018

HAL is a multi-disciplinary open access archive for the deposit and dissemination of scientific research documents, whether they are published or not. The documents may come from teaching and research institutions in France or abroad, or from public or private research centers.
L'archive ouverte pluridisciplinaire HAL, est destinée au dépôt et à la diffusion de documents scientifiques de niveau recherche, publiés ou non, émanant des établissements d'enseignement et de recherche français ou étrangers, des laboratoires publics ou privés.

\section{(c)(1)}

Distributed under a Creative Commons Attribution| 4.0 International License 


\title{
Digital Safety and Responsible Use within a Primary School Ecosystems Community in Aotearoa/ New Zealand
}

\author{
Nicki Dabner \\ E-Learning Lab, University of Canterbury, New Zealand \\ Nicki.dabner@canterbury.ac.nz
}

\begin{abstract}
With the New Zealand Ministry of Educations' emphasis upon e-Learning in educational settings, and the correlating increase in approaches to learning with digital technologies in New Zealand primary schools, primary school-aged students in New Zealand are increasingly using digital devices in school settings and at a progressively earlier age. As availability of digital devices outside of school also increases and the boundaries between usages blur, there is an imperative to prepare primary them to use digital devices safely and responsibly across multiple contexts, and for multiple purposes. Implementing a school-wide, cross-sector, multistakeholder approach has been proposed as the most effective way to prepare young people in this area. However, little is known about how such an approach is actualized in primary school settings, and the benefits and challenges associated with its adoption. Drawing upon ecological systems theory, this interpretive case study will examine how one New Zealand primary school addresses digital safety and responsible use within the school ecosystems community, how they engage with individuals, groups or organizations situated within other ecosystem communities, and the drivers, enablers, barriers and tensions they experience within these endeavours.
\end{abstract}

Keywords: Education, Digital Devices, Digital Safety and Responsibility, Ecologies, Case Study

\section{Introduction}

Corresponding with the increased availability and use of digital technologies in many societies, there is increasing concern regarding the safety, behaviour, understandings and wellness of digital technology users who use these technologies to engage with digital content and participate within digital environments [1,2]. The New Zealand Ministry of Education recognise both the pivotal role digital technologies have transforming teaching and learning in New Zealand schools [3] and the imperative for the education sector to ensure students are equipped to engage effectively and safely when using these technologies [4]. The term 'safety' is often used to describe things that afford security and protection from danger. Maurice at al [5] define safety as "a state in which hazards and conditions leading to physical, psychological or material harm are controlled in order to preserve the health and well-being of individuals and the community" (p.234). The notion of 'risk' is always associated with safety. Cibbora [6] describes risks as actions that included an element of uncertainty, that 
have a probability of occurrence and that could potentially have undesirable outcomes or consequences. Staksrud and Livingstone [7] classified three types of risks associated with children's participation in online activities using digital technologies (p. 368);

- Content risks: where children are the recipient of often mass-produced images and text (child as recipient);

- Contact risks: where children participate in adult- initiated online activities (child as participant); and

- Conduct risks: where children participate in peer to peer exchanges (child as actor)

Each of these risk categories have been identified in New Zealand, with associated issues such as cyberbullying [8,9,10], information disclosure [11,12], overuse [13,14] and unsafe use [15] now impacting primary school-aged students. All schools in New Zealand have a legal responsibility to ensure the safety of students during school hours. To minimise the risks associated with digital safety, schools may implement strategies to ensure the safety of students within the school environment, for example blocking access to websites and monitoring digital technology use by students. However, many of these strategies have little impact when the students leave the school grounds. Thus, the Ministry of Education identify digital fluency and ensuring safe online learning environments as priorities for New Zealand schools [16], proposing that equipping learners with 21st century skills and digital competencies requires a cohesive, coordinated, cross-sector and multi-stakeholder approach to change within the New Zealand education system. Key organisations with an interest in 'Internet Safety' in New Zealand $[17,18,19]$ support this assertion, one stating that there has never been a greater need for schools and communities to work together as young people in New Zealand access the internet with increasing frequency via multiple access points, with a continuing trend towards mobile access.

Although one New Zealand school-based case study [20] has investigated the implementation of digital citizenship, a concept often associated with digital safety, within a secondary school setting, there are major gaps in research relating to primary school contexts and more notably, research investigating the ways teachers and schools work with parents/whānau and members of the wider educational community, who also reside within the educational ecosystem in New Zealand. The case study described in this thesis is intended to address this issue. The overarching question guiding this thesis is: How does a primary school approach digital safety and responsible use within their school ecosystems community? The following subquestions will focus the investigation.

With regard to school leaders, teachers and school support staff:

a) What perceptions do they have about digital safety and responsible use?

b) How are digital devices used by students?

c) How is risk constructed and managed?

d) How is digital safety and responsible use encouraged?

e) How do they work together, and with parents/whānau and members of the wider school community, to support digital safety and responsible use by their children?

Bronfenbrenner's 'Ecological Systems Theory' [21] and Davis' 'Arena with Change with Digital Technologies' $[22,23]$ will provide the theoretical frameworks 
for this study. Notions of 'space and place' [24] and 'networks', increasingly relevant to research involving digital technologies, will also be examined.

\section{Methodology}

Case Study methodologies as proposed by Stake [25] and Merriam [26] both resonate with me as a researcher as they closely align with my epistemological (social constructivist/ social-cultural) orientation. They also provide best fit with the study as a naturalistic, interpretative inquiry. The case study will conducted in a primary school in the local region and undertaken over a one-year period. Purposive sampling will been used to identify potentially suitable schools for the study, the criteria being; age band coverage (spanning ages five-thirteen), high usage of digital technologies and collaborative teaching approaches, and evidence of a BYOD, a 'bring your own device', policy within the school. Although the unit of analysis will be the school and the parental community within this school, the interactions with external networks across other layers of the ecosystem will also be also considered. Ethical considerations will be identified and discussed with the school, and ethical clearance gained prior to the study commencing. Qualitative data will be collected utilising a range of appropriate data gathering techniques including interviews, observations and document review/analysis. Data analysis will be conducted recursively in association with data collection, and will involve forms of analysis that may include categorical aggregation, content analysis, analytical induction and direct interpretation. Strategies to enhance credibility and trustworthiness will include reflective commentary, triangulation (data/theory), member checks, and multiple observations conducted over the period of one year. Researcher positioning, and disclosure of bias will be declared and discussed to enhance data dependability. This research and the resulting thesis will draw upon my individual $[27,28,29,30,31]$ and collective $[32,33,34]$ experiences as a researcher of digital technologies, digital environments and online communities, many years of experience as an educator working in and with primary schools in New Zealand, and my enduring fascination and critical appraisal of the ways digital technologies and environments are impacting the way people live, learn and communicate in society. It is intended but not assured that the findings exemplify the myriad of ways digital safety and responsible use are being addressed across the educational ecosystem, thus potentially providing insights for the reader that could inform future policy directions in New Zealand and school practices beyond New Zealand. It is highly likely the findings will expose questions and issues that justify further examination in future studies. As such, this thesis will make a valuable contribution to research and literature in this field. Importantly, it also makes a valuable contribution to the development of this author as a quality researcher.

Acknowledgements. The author would like to acknowledge the encouragement provided by her Doctoral Supervisor to present this extended abstract at the consortium, as a valuable way to refine her thinking and the subsequent case study. 


\section{References}

1. Ministry of United Nations Educational, Scientific, and Cultural Organization (UNESCO).: Fostering Digital Citizenship Through Safe and Responsible Use of ICT: A Review of Current Status in Asia and the Pacific as of December 2014 (2015).

2. Ribble, M., Miller, T. N.: Educational Leadership in an Online World: Connecting Students to Technology Responsibly, Safely, and Ethically. Journal of Asynchronous Learning Networks 17(1), 135-143 (2013).

3. Ministry of Education.: New Zealand Education in 2025; Lifelong Learners in a Connected World (Draft). Ministry of Education, Wellington (2015).

4. The $21^{\text {st }}$ Century Learning Reference Group.: Future-focussed Learning in Connected Communities: A Report by the $21^{\text {st }}$ Century Learning Reference group (2014).

5. https://www.educationcounts.govt.nz/publications/schooling/109306

6. $\quad$ Maurice, P., Lavoie, M., Laflamme, L., Svanström, L., Romer, C., Anderson, R.: Safety and Safety Promotion: Definitions for Operational Developments. Injury Control and Safety Promotion, 8(4), 237-240 (2001).

7. Cibbora, C.: Imbrication of Representations: Risk and Digital Technologies. Journal of Management Studies Vol 43, 1339-1356 (2006).

8. Staksrud, E., Livingstone, S.: Children and Online Risk: Powerless Victims or Resourceful Participants? Information, Communication \& Society 12(3), 364-378 (2009).

9. Von Marées, N., Petermann, F.: Cyberbullying: An Increasing Challenge for Schools. School Psychology International, 3(55), 467-476 (2012).

10. Monks, C., Robinson, S., Worlidge, P.: The Emergence of Cyberbullying: A Survey of Primary School Pupils' Perceptions and Experiences. School Psychology International, 3(55), 477-491 (2012).

11. Holfeld, B., Grabe, M.: Middle School Students' Perceptions of and Responses to Cyber Bullying. Journal of Educational Computing Research, 46(4) 395-413 (2012).

12. Davis, K., James, C.: Tweens' Conceptions of Privacy Online: Implications for Educators. Learning, Media and Technology, 38(1), 4-25, (2013).

13. De Souza, Z., Dick, G.: Information Disclosure on MySpace: The What, the Why and The Implications. Pastoral Care in Education, 26(3), 143-157 (2008).

14. Seomun, G., Lee, J., Kim, E., Im, M., Kim, M., Park, S., Lee, Y.: Health Effects of Digital Textbooks on School-Age Children: A Grounded Theory Approach. Western Journal of Nursing Research, 35(9), 1184-1204 (2013).

15. Gutnick, A., Robb, M., Takeuchi, L., Kotler, J. Always Connected: The New Digital Media Habits of Young Children. New York: The Joan Ganz Cooney Centre at Sesame Workshop (2011).

16. Valcke, M., De Wever, B., Van Keer, H. Schellens, T.: Long-Term Study of Safe Internet Use of Young children. Computers \& Education, 57(1) 1292-1305 (2011).

17. Ministry of Education.: Towards Digital Fluency (2015) http://www.education.govt.nz/assets/Uploads/Towards-Digital-Fluency.pdf

18. Netsafe New Zealand.: From Literacy to Fluency to Citizenship: Digital Citizenship in Education. White paper. Netsafe; Auckland (2016). https://www.netsafe.org.nz/wpcontent/uploads/2016/11/NETSAFE-WHITEPAPER-From-literacy-to-fluency-tocitizenship.pdf

19. National Library of New Zealand. Digital Citizenship in Schools (2016). http://schools.natlib.govt.nz/supporting-learners/digital-citizenship/digital-citizenshipschools\#Defining-Digital-Citizenship

20. Research New Zealand.: Digital Technologies in New Zealand Schools: A Report Prepared for the 2020 Communications Trust (2014). http://2020.org.nz/wpcontent/uploads/2014/07/Digital-Technologies-in-School-2014-FINAL.pdf 
21. Land, J.: A Case Study to Investigate the Implementation of a Blended Digital Citizenship Course within a New Zealand Secondary School. Unpublished Thesis (2013).

22. Bronfenbrenner, U.: The Ecology of Human Development. Harvard University Press: Cambridge, MA (1979).

23. Davis, N., Eickelmann, B., Zaka, P. Restructuring of Educational Systems in the Digital Age from a Co-evolutionary Perspective. Journal of Computer Assisted Learning 29(5), 438-450 (2013).

24. Davis, N.: How May Teacher Learning be Promoted for Educational Renewal with IT? In: Voogt, J., Knezek, G. (eds.) International Handbook of Information Technology in Primary and Secondary Education, 507-520. Elsevier; Amsterdam (2008).

25. Ciolfi, L.: Space and Place in Digital Technology Research: A Theoretical Overview. In: Price, S., Jewitt, C., Barry, B. (eds.) The Sage Handbook of Digital Technology Research. Sage Publications: London (2013).

26. Stake, R.: The Art of Case Study Research. SAGE Publications; Thousand Oaks, California (1995).

27. Merriam, S.: Qualitative Research and Case Study Applications in Education. JosseyBass, San Francisco (1998).

28. Dabner, N.: Weaving Digital Citizenship within Pre-Service Teacher Education: Preparing Graduate Students for High-Quality Educational Practices within Modern Learning Environments and the Virtual World. Las Vegas, NV, USA: Society for Information Technology \& Teacher Education International Conference (SITE), 2-6 Mar 2015. In SITE Conference Proceedings 2015 (1), 3115-3120.

29. Dabner, N.: An Evaluative Study of the Use of e-Portfolio's within a Graduate Teacher Education Qualification in New Zealand. Christchurch, New Zealand: Society of Information Technology in Teacher Education International Symposium 2014 (SITE), 28-29 Apr 2014.

30. Dabner, N.: 'Breaking Ground' in the Use of Social Media: A Case Study of a University Earthquake Response to Inform Educational Design with Facebook. The Internet and Higher Education, 15(1), 69-78 (2011).

31. Dabner, N: Design to Support Distance Teacher Education Communities: A Case Study of a Student-Student e-Mentoring Initiative. Nashville, TN, USA: 22nd Annual Society for Information Technology \& Teacher Education (SITE) International Conference, 7-11 Mar 2011. In SITE 2011(1), 218-223. http://www.editlib.org/p/36262.

32. Dabner, N.: GradNet: Online communities providing support for beginning teachers during the provisional registration period in New Zealand. Australian Teacher Education Association (ATEA) Conference 2006, 5-8 Jul (2006), Freemantle, Australia. In Making Teaching Public: Reforms in Teacher Education: Proceedings of the 2006 Australian Teacher Education National Conference: 67-74.

33. Mackey, J., Davis, N., Dabner, N.: Relevant, Current and Sustainable Digital Strategies to Prepare Future Teachers to Lead e-Learning.: 29th annual Ascilite conference, 25-28 Nov (2012), Wellington, New Zealand.

34. Dabner, N., Davis, N., Zaka, P. Authentic Project-based Design of Professional Development for Teachers Studying Online and Blended teaching. Contemporary Issues in Technology and Teacher Education 12(1), 71-114 (2012).

35. Dabner, N., Chowfin, A.: Project-Based Professional Development: Reflections In And On Action Implementing Blended Learning With Primary School Students. Computers In New Zealand Schools, 23(3), 248-261(2011) 